\title{
COPTOCAMPYLODON PANTICI N. MORPHO SP. FROM THE TURONIAN OF NW SERBIA
}

\author{
DARIVOJKA LJUBOVIĆ-OBRADOVIĆ ${ }^{1}$ \& RAJKA RADOIČIĆ ${ }^{2}$
}

\begin{abstract}
This note describes Coptocampylodon pantici, a new morpho species from Upper Cretaceous outcrops of the Poćuta region (NW Serbia). Based on the rudists in superincumbent calcarenites and planktonic foraminifers of the $D$. concavata Zone overlying the calcarenites, the shallow water "Poćuta limestone" is dated Turonian. The genus Coptocampylodon Elliott is emended.
\end{abstract}

Keywords: Dasycladales, new morpho species, Turonian, NW Serbia

\section{Introduction}

In the Valjevska Podgorina region of NW Serbia, Upper Cretaceous deposits are found in the Poćuta area and in a small tract north of the Sušica river (Fig. 1). In northern portion of the region the oldest rocks of Cretaceous age are shallow water Turonian carbonates ("Poćuta limestone") that rest on karstified Triassic limestones with minor bauxite occurrences (Pejović and Radoičić, 1981). To the south, Upper Cretaceous rocks are in tectonic contact with older formations.

North of the Sušica river, in Ječmenje village, first author (D.Lj.O) sampled ten metres of a Turonian succession. The lowermost beds, above the Triassic karstified surface, contain scarce foraminifers including Vidalina hispanica Schlumberger, Pseudocyclammina sphaeroidea Gendrot, Moncharmontia apenninica (De Castro) and Nezzazatinella sp.. In addition to these foraminifers the beds making up the fifth metre contains algae including Falsolikanella hammudai (Radoičić), Terquemella sp., Pseudolithothamnium album (Pfender) and abundant coptocampylodons, belonging to a new taxon: Coptocampylodon pantici n. morpho sp.

Elliott (1963) described a new genus and species, Coptocampylodon lineolatus (Problematica) from the Lower Cretaceous of Iraq. Fossils of the same type are known from other regions and were originally assigned to the Aciculariae, or "microfossils similar to Aciculariae" (Elliott, 1963; Radoičić, 1968). In his discussion of the possible biological nature of these fossils, Elliott presumed as the most likely affiliation, their similarity to the skeletal remains of some small octocorals.

From the Kimmeridgian of NW Germany, Gramann, (1966) described fecal pellets ("little rods of sediment with longitudinal furrows") in open nomenclature under the name Coprulus. Cuvillier et al. (1969) placed Coptocampylodon in the group Coprulus Gramann. Consequently, Granier and Deloffre (1993) excluded Coptocampylodon lineolatus from the Dasycladales.

\footnotetext{
${ }^{1}$ Geozavod - Geological Institute, Karađorđeva 48, 11000 Belgrade.

${ }^{2}$ Kralja Petra I 38, 11000 Belgrade, rradoicic@sezampro.yu
} 


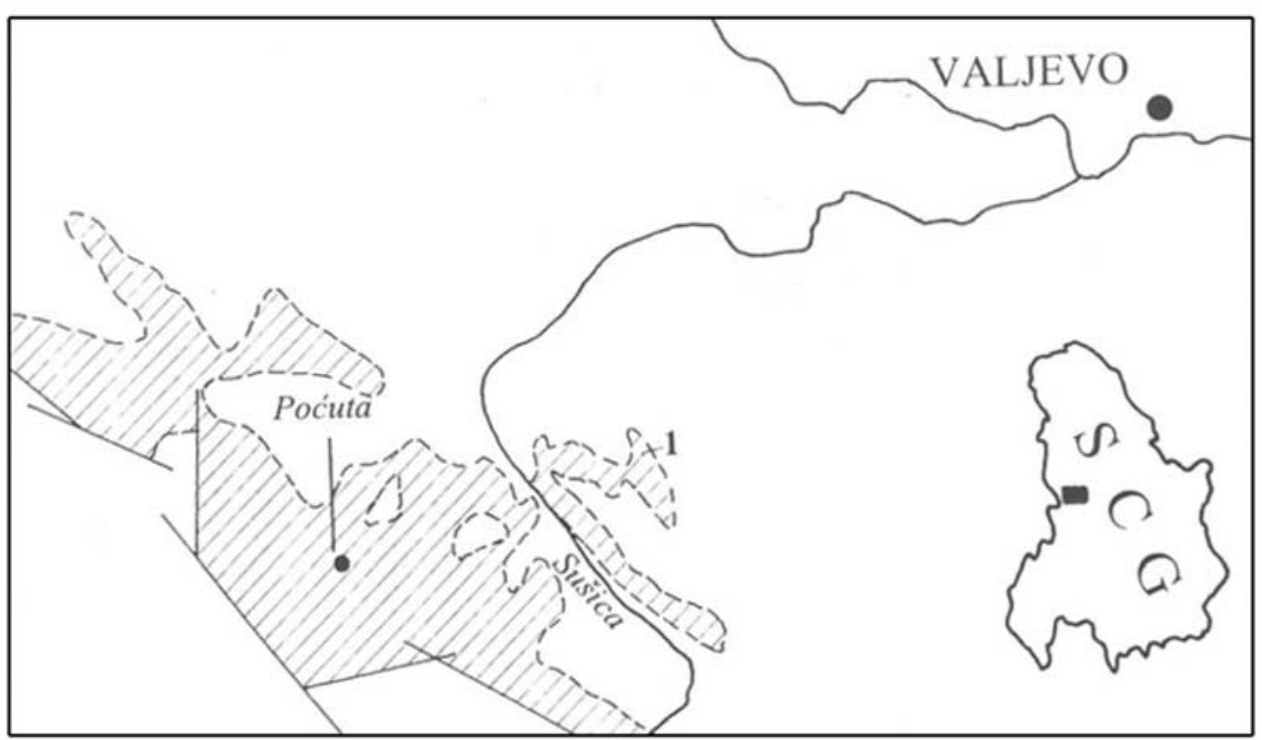

Fig. 1. Distribution of Cretaceous strata in the Poćuta area, NW Serbia (based on: Milovanović \& Cirić: Geological Map of Serbia, 1968, simplified)

Coptocampylodons were described as solid calcareous bodies with a gently curved longitudinal axis and a grooved outer surface. In thin section, transverse cuts show stellate structures with truncated rays (Elliott, 1963).

The dasycladalean nature of coptocampylodons was noted in a specimen of Selliporella neocomiensis (=Triploporella neocomiensis, Radoičić, 1968, PI. 1, fig. 1; see: Bucur and Săsăran, 2003). Coptocampylodons are actually dislocated tufts of the secondary laterals of some species of the genera Selliporella, Suppiluliumaella (Radoičić, 1972, Fig. 1b), Triploporella, and probably others as well. Sections similar to those of the coptocampylodon type are also found in tufts of the primary upwardcurved laterals of the Permian genus Kochanskyella - K. tulipa (Milanović, 1974). The holotype of C. lineolatus (Elliott 1963, pl. 46, fig. 4) is an isolated specimen the proximal part of a broken R2 tuft. In pl. 46, fig. 6, the surface of the transverse section of an isolated specimen is shown. It evidently corresponds to the transverse section of fig. 8, pl. 46. This transverse sections of Coptocampylodon lineolatus markedly differs from a Coprulus ("little rods of sediment ..."). The external similarity of Coptocampylodon lineolatus (longitudinal grooves) with some Coprulus (Gramann, pl. 1, figs. 1a-4b; Cuvillier et al., pl. 2, figs. 6-9) is a case of homeomorphism.

\section{Paleontological description}

Morpho genus Coptocampylodon Elliott, 1963, emend.

Small calcareous bodies which represent dislocated tufts of the elongate trichophorous secondary laterals of some dasycladalean species, perhaps even of several genera, which occur as scattered units in sediments. 
In addition to the type-species (with 5-8 pores/grooves), other Coptocampylodon have been described: $C$. fontis Patrulius from the Lower Cretaceous of Romania (9-15 pores/canals) and C. elliotti Radoičić from the Albian (revised age!) of the Mirdita Zone and the Outer Dinarides (6-9 pores/canals). Depending on the state of preservation, in tranverse section the laterals appear as a row of peripheral pores or, where outer calcification is absent, as a stellate structure with truncated rays. The space enclosed by the laterals appears in transverse sections as central cavity (except where the calcareous bodies are completely recrystallized).

Coptocampylodon pantici n. morpho sp.

(PI. 1, Figs. 1-5, PI. 2, Figs. 1-4, PI. 3, Figs. 1, 2)

O r i g i $n$ of $n$ a $m$ e: The species is dedicated to Professor Nikola Pantić (University of Belgrade) as a tribute to his contributions to the paleobotany and geology of Serbia.

$\mathrm{H}$ o I o $\mathrm{t}$ y $\mathrm{p}$ e: Axial section of a calcareous body, with a slightly curved basal part as shown in PI. 1, Fig. 4 (arrow), thin section RR465l; Collection R. Radoičić housed in Geozavod, Geological Institute, Belgrade.

I s o t y $\mathrm{p}$ e s: Numerous transverse, oblique and longitudinal sections some of which are illustrated in PI. 1-3. Thin sections RR4665-4667.

T y $p$ e - I o c a I i t y: Surroundings of the village of Ječmenje, Valjevska Podgorina, NW Serbia; Gaus Krueger coordinates N 4895680, E 7403140.

$\mathrm{D}$ i a g $\mathrm{n}$ o s i s: Tufts consisting of four, seldom five fused canals, originating from trichophorous secondary laterals the basal portion of which is slightly curved. Transverse sections of units with four canals look like a Maltese cross.

The trichophorous shape of the laterals determines the shape of the tuft; consequently, transverse sections of the basal part are larger (up to 0, $250 \mathrm{~mm}$ ) than those that cut it higher. The curve of the tuft is visible only in very few axialsubaxial sections. Most longitudinal and oblique-longitudinal sections cut through the rectilinear part of the tuft which is at most $0.960 \mathrm{~mm}$ long. The calcification of the tuft surface is seldom preserved.

$\mathrm{C} \circ \mathrm{m} \mathrm{p}$ a r i s o $\mathrm{n} \mathrm{s}$ : Coptocampylodon pantici differs significantly from species having many more canals. Coptocampylodon pantici may represent tufts of the secondary laterals of an indeterminate species (genus Triploporella?) that is shown in PI. 1, Fig. 6 (here only a calcified axis with a few moulds of primary laterals is preserved).

A g e: The Poćuta limestone is dated Turonian based on the identification of rudists in the overlying calcarenites and of the planktonic foraminifers of the $D$. concavata zone in the succeeding pelagic carbonates (Pejović and Radoičić, 1968; Radoičić, 1978, 2003).

\section{Accnowledgements}

The authors thank Marc A. Conrad (Geneve), Bruno Granier (Paris) and Nestor Sander (USA) for their comments and English improvement of the manuscript. 


\section{REFERENCES}

Bucur, I.I. \& Săsăran, E. 2003: Selliporella neocomiensis Radoicic 1975 (non 1963), nov. comb. Acta Micropaleont. Sinica, 20, 1, 57-66

Elliott, G.F. 1963: Problematic microfossils from the Cretaceous and Palaeocene of the Middle East. Paleontology, Vol. 6, 2, 293-300, London.

Cuvillier, J., Bassoullet, J. P., Fourcade, E. 1969: Coprolithes du Jurassique et du Crétacé d’Espagne et de quelques autres régions. Revue de Micropaléont., vol. 11, 4, 183-190. Paris.

Granier, B. \& Deloffre, R. 1993: Inventaire critique des algues Dasycladales fossiles. $I^{\circ}$ partie - Les AlguesDasycladales du Jurassique et du Crétacé. Rev. Paléobiol. 12, 1, 19-65, Genève

Milanović, M. 1974: Kochanskyella (Chlorophyta, Dasycladaceae), a new Permian Genus of the Mt. Velebit, Croatia. Geološki vjesnik, 27, 127-132, Zagreb.

Milovanović, B., Ćirić, B. 1968: Carte géologique de la R. S. de Serbie. Inst. de rech. géol. et géoph., Belgrade.

Pejović, D., Radoičić, R. 1981: A contribution to the biostratigraphy of the Poćuta bauxite region (western Serbia). Glas SANU, Cl. sc. nat. et math. 48, 21-26, Beograd.

Radoičić, R. 1969: Coptocampylodons de certains sédiments jurassiques et crétacés de la Yougoslavie. Vesnik, ser. A, 27, 191-200, Beograd.

Radoičić, R. 1972: A new Neocomian Dasycladacea Suppiluliuaemella gocanini from the environs of Orahovac (Mirdita Zone). Bull. scient., Cons. des Acad. des Sc. Et des Arts de la RFY, sec. A, tome 17, 11-12, 364-365, Zagreb.

Radoičić, R. 2003: Permocalculus nikolapantici (Udoteaceae?) from the Upper Turonian of the NW Serbia. Bull. TCXXVIII Acad. Serbe sc. Arts, sc. nat., 42, p. 239-259.

\section{PLATES}

Plate I

Figs. 1-5 Coptocampylodon pantici n. morpho sp.

Figs. 1-3, 5. transverse sections, (circa 140x). Thin sections RR4657, 4655. Fig. 4 Holotype: axial section (arrow), oblique and transverse-oblique sections, in the upper part of the figure: Terquemella sp., Thin section RR4651;

Fig. 6 ? Triploporella, arrows: moulds of primary laterals. (75x). Thin section RR4655.

Plate II

Figs. 1-4 Coptocampylodon pantici n. morpho sp., oblique, longitudinal and transverse sections, ( 5x). Thin sections RR4657, 4656 and 4655 (Terquemella sp. In Fig. 1).

Plate III

Figs. 1-2 Coptocampylodon pantici n. morpho sp., transverse and transverse-oblique sections, (5x), Thin sections RR4656 and 4657.

Figs. 3-8 Falsolikanella hammudai (Radoičić), various sections, (35x), (with C. pantici in figs. 3, 4 and 6), Thin sections RR4655 and 4657. 
Plate I

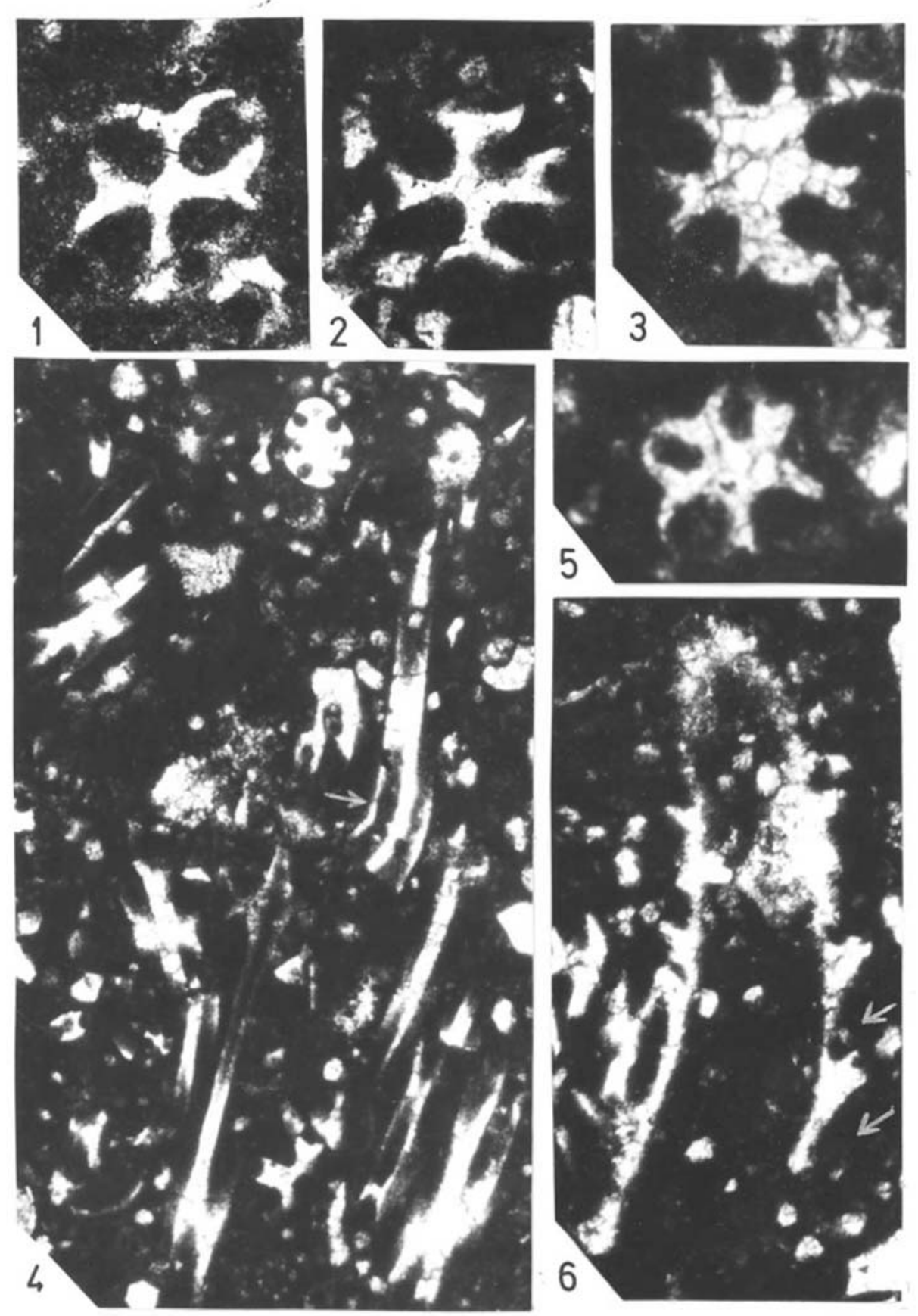




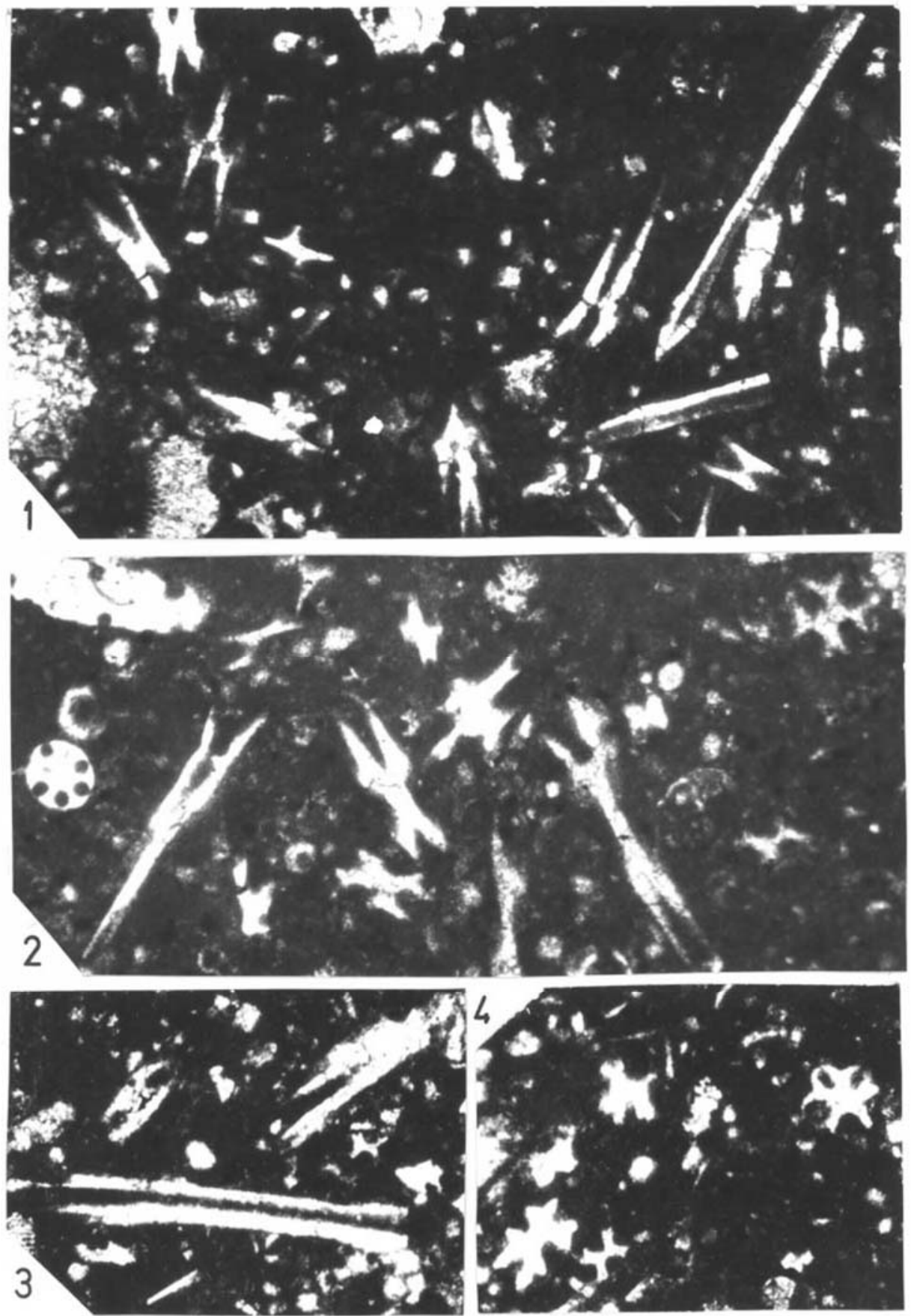



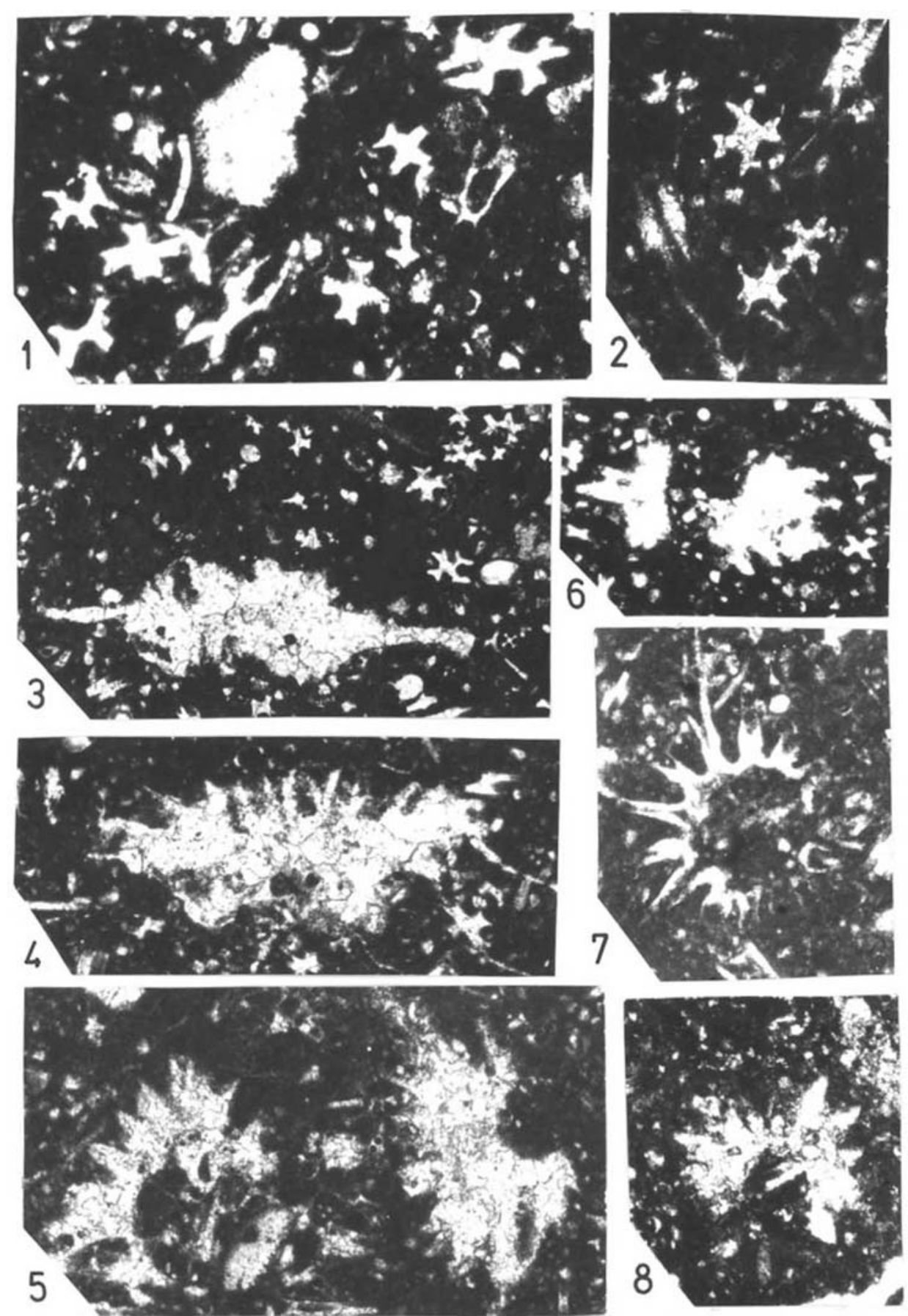